\title{
PENGARUH PENDAPATAN USAHA DAN BIAYA OPERASIONAL TERHADAP LABA BERSIH
}

\author{
Ujang Suhaemi \\ Universitas Singaperbangsa Karawang \\ ujangsuhaemi59@gmail.com \\ Nanu Hasanuh \\ Universitas Singaperbangsa Karawang
}

\begin{abstract}
The purpose of this study is to find out how much influence operating income and operating costs have on net income incompanies property and real estate listed on the Indonesia Stock Exchange for the 20152019 period. The verification method with a quantitative approach is the method used in this study which is sourced from the income statement ofcompanies property and real estate. Purposive sampling was used to take samples so that 85 were taken from the income statements of 17 companies for the 2015-2019 period. To simplify the analysis process, multiple linear analysis was used in this study. The results showed that operating income (XI) partially affected net income where the t table value (8.455 > $1.89932)$ and the significance value $(0.000<0.05)$. Operating costs (X2) partially affect net income as evidenced by the value of $t$ table $(-6.182<1.98932)$ and significance $(0.000>0.05)$. And the two $X$ variables simultaneously affect net income where the calculated $F$ value is greater than the $F$ table value (38.633 > 3.11). And a significance value of 0.000 which means it is smaller than $0.05(0.000<0.05)$.
\end{abstract}

Keywords : Operating Income, Operating Expenses and Net Profit.

\section{PENDAHULUAN}

Perkembangan dunia bisnis di era ini semakin cepat, hal ini menyebabkan tuntutan terhadap perusahaan untuk terus mengexplor bisnisnya dengan menarik pangsa pasar. Dalam menghadapinya perusahaan harus dapat bersaing dengan perusahaan lain. Pihak manajemen harus menyusun perencanaan yang lebih baik dibanding perusahaan pesaing serta dituntut untuk lebih saksama dan berhati-hati dalam melaksanakan kegiatannya.

Tujuan yg paling utama mendirikan perusahaan adalah untuk mendapatkan laba. Perusahaan diharuskan mengelola perencanaan laba dengan baik agar mendapatkan hasil yang maksimal. Laba yang didapat perusahaan biasanya menjadi tolok ukur untuk menilai keberhasilan perusahaan dalam mengelola sebuah perusahaan. Oleh sebab itu, manajemen perusahaan dianjurkan untuk dapat meningkatkan performa perusahaan dan memaksimalkan aset yang dipunyai agar mampu mempertahankan going concern perusahaan.

Jika perusahaan mendapatkan pendapatan usaha yang kurang maksimal hal tersebut dapat membuat turunnya laba. Biaya operasional yang tinggi dapat menyebabkan laba mengalami penurunan, begitu juga sebaliknya. Sehingga, untuk mendapatkan laba yang besar perlu dilakukan pemantauan biaya-biaya yang digunakan dan mengaturnya secara efisien, hal ini bisa membuat perusahaan mendapat laba sesuai dengan yang diinginkan.

Bersamaan dengan berkembangnya dunia bisnis di Indonesia, pemerintah sepakat untuk menggiatkan pertumbuhan sektor property dan real esteate yang selama 5 tahun terakhir ini mengalami penurunan. Dalam pembangunan perekonomian nasional sektor property dan real

Competitive Jurnal Akuntansi dan Keuangan, 5(2), 2021 
estate memiliki peran penting. Dilansir dari detikFinance.com, dalam beberapa tahu terakhir sektor property mengalami tren yang terus melambat di Indonesia. Pertumbuhannya pun dibawah dari pertumbuhan ekonomi Indonesia.

Pemerintah berupaya meningkatkan kembali pertumbuhan sektor property sehingga pendapatan usaha dan laba bersih perusahaan sektor property kembali meningkat dengan cara mengeluarkan kebijakan dalam upaya peningkatan pada sektor property yaitu kenaikan batas kegiatan jual beli yang dikenakan PPnBM.

Tabel 1 menunjukkan tingkat rata-rata pendapatan usaha, biaya operasional dan laba bersih faktor yang dapat memepengaruhi laba bersih diantaranya pendapatan usaha dan biaya operasional. (Efilia, 2014), (Anjani, 2013) dan (Pasca, 2019) merupakan peneliti yang pernah melakukan penelitian tentang laba bersih.

Penelitian ini mempunyai tujuan, diantaranya; besarnya pengaruh dari masingmasing variabel $\mathrm{X}$ terhadap variabel $\mathrm{Y}$ secara parsial. Serta pengaruh secara simultan antara variabel $\mathrm{X}$ tehadap variabel $\mathrm{Y}$ pada perusahaan property dan real estate yang ada di BEI periode 2015-2019.

Tabel 1 Rata-rata Pendapatan Usaha, Biaya Operasional dan Laba Bersih Sektor Property dan Real Estate di BEI Periode 2015-2019

\begin{tabular}{r|r|r|c}
\hline Tahun & Pendapatan Usaha & Biaya Operasional & Laba Bersih \\
\hline $\mathbf{2 0 1 5}$ & $3,924,935,359,100$ & $1,016,373,258,072$ & $750,202,010,072$ \\
\hline $\mathbf{2 0 1 6}$ & $4,222,850,157,329$ & $1,156,081,283,793$ & $678,578,360,566$ \\
\hline $\mathbf{2 0 1 7}$ & $4,620,569,505,908$ & $1,419,402,620,700$ & $631,411,458,308$ \\
\hline $\mathbf{2 0 1 8}$ & $4,519,100,395,999$ & $1,403,974,224,786$ & $917,487,348,467$ \\
\hline $\mathbf{2 0 1 9}$ & $4,363,371,230,142$ & $1,497,389,696,200$ & $71,316,692,636$ \\
Sumber : BEI dan diolah penulis, 2020.
\end{tabular}

17 perusahaan property dan real estate yang dijadikan sampel penelitian. Dapat dilihat dari tabel diatas nilai dari setiap variabel berfluktuasi. Niai pendapatan usaha yang rendah terjadi pada tahun 2015 dengan pendapatan usaha sebesar $\mathrm{Rp} 3,924,935,359,100$ berarti bahwa perusahaan tidak dapat memperoleh laba yang lebih besar dalam hal pengelolaan aset yang dipunyai oleh perusahaan dan juga yang dikelola oleh manajemen perusahaan. Biaya operasional dengan nilai tertinggi terjadi pada tahun 2019 sebesar Rp 1,497,389,696,200 mengindikasikan pada tahun tersebut terjadi penurunan laba bersih.

Para peneliti terdahulu menyatakan bahwa

\section{KAJIAN PUSTAKA DAN PENGEMBANGAN HIPOTESIS \\ Pendapatan usaha}

Pendapatan usaha adalah "Arus masuk aktiva entitas dan/atau penyelesaian kewajibannya (atau kombinasi dari keduanya), yang ditimbulkan oleh pengiriman/penyerahan atau produksi barang, pemberian jasa, atau kegiatan menghasilkan laba lainnya yang termasuk bagian dari operasi sentral perusahaan yang berkelanjutan selama suatu periode" Menurut (Rahmawati, 2020)

\section{Biaya Operasional}

(Widearahim, 2019) mengatakan bahwa 
biaya operasi (operating cost) merupakan biaya yang terkait dengan operasional perusahaan yang meliputi biaya penjualan dan administrasi, biaya iklan, biaya penyusutan, serta perbaikan dan pemeliharaan.

\section{Laba Bersih}

Laba bersih (Net Profit) adalah laba yang telah dikurangi biaya-biaya perusahaan dalam suatu periode tertentu termasuk pajak (Elsa et al., 2019).

Dari definisi di atas laba bersih merupakan selisih lebih pendapatan atau beban yang merupakan kenaikan bersih setelah dikurangi biaya bunga dan pajak yang berasal dari aktivitas usaha selama periode tertentu.

\section{Pengaruh Pendapatan Usaha Terhadap Laba Bersih}

Tingkat laba bersih yang didapat sebuah perusahaan dapat menjadi tolok ukur keberhasilan manajemen perusahaan dan capaian laba bersih merupakan faktor yang menentukan going concern perusahaan.

Pendapatan yang lebih besar dari biaya akan menyebabkan perusahaan laba, sebaliknya apabila pendapatan lebih kecil dari biaya yang dikeluarkan maka akan mendapatkan kerugian (Efilia, 2014) mengatakan bahwa pendapatan usaha berpengaruh terhadap laba bersih, apabila pendapatan usaha yang didapat perusahaan tinggi maka akan menyebabkan laba bersih perusahaan akan tinggi juga.

H1 : Pendapatan usaha berpengaruh terhadap laba bersih

\section{Pengaruh Biaya Operasional Terhadap Laba Bersih}

Menekan budget seefisien mungkin dan menggunakan sebaik-baiknya merupakan hal yang perlu dilakukan supaya perusahaan dapat mencapai laba sesuai target. Hal ini pada hakikatnya hubungan antara laba dan biaya bertolak belakang. Apabila biaya yang dikeluarkan besar maka laba akan mengalami penurunan serta apabila laba bertambah maka biaya yang dikeluarkan akan lebih sedikit. Biaya yang perlu diminimalisasi adalah biaya variabel. Karena biaya variabel selalu berubah-ubah mengikuti volume bisnis. Tapi sebelum melakukan penekanan biaya khususnya biaya variabel maka harus dipahami sebaik mungkin apakah biaya tersebut perlu atau tidak untuk dikurangi.

Menurut (Ratnasih, 2017), apabila manajemen perusahaan bisa menghemat biaya, laba bersih dapat ditingkatkan oleh perusahaan. Sebaliknya bila perusahaan boros dalam mengeluarkan biaya maka akan mengakibatkan penurunan laba bersih.

$\mathrm{H} 2$ : Biaya operasional berpengaruh terhadap laba bersih.

\section{Pengaruh Pendapatan Usaha dan Biaya Operasional Terhadap Laba Bersih}

Menurut peneliti (Rahmawati, 2020) bahwa laba bersih dipengaruhi secara signifikan oleh pendapatan usaha dan biaya operasional. Pendapatan usaha mempunyai hubungan yang sangat kuta dengan laba bersih dan berbanding lurus. Sedangkan biaya operasional berbanding terbalik dengan laba bersih artinya ketika biaya operasional meningkat maka laba bersih akan menurun.

H3: Pendapatan usaha dan biaya operasional berpengaruh secara simultan terhadap laba bersih.

\section{METODOLOGI PENELITIAN \\ Populasi dan Sampel}

Populasi yaang diteliti oleh peneliti merupakan perusahaan property dan real estate yang listing di BEI periode 2015-2019 yaitu sebanyak 62 perusahaan. Purposive sampling digunakan untuk menyeleksi sampel dalam penelitian ini. Sebanyak 85 sampel berhasil didapat dari hasil purposive sampling perusahaan sektor property dan real estate yang terdaftar di BEI yang telah memenuhi kriteria sebagai sampel penelitian dari 17 perusahaan selama 5 tahun penelitian.

\section{Metode Analisis Data}

Dalam penelitian ini, digunakan analisis regresi linear berganda dengan dibantu oleh 
software SPSS 22. Dengan menggunakan Analisis regresi linier berganda kita dapat menghitung seberapa besar hubungan antara variabel $\mathrm{X}$ dan variabel $\mathrm{Y}$. Pengaruh pendapatan usaha dan biaya operasional terhadap laba bersih dapat dilihat dengan persamaan sebagai berikut:

$$
\mathrm{Y}=\alpha+\beta 1 \mathrm{X} 1+\beta 2 \mathrm{X} 2+\varepsilon
$$

Dimana :

$\mathrm{Y}=$ Laba Bersih

$\alpha=$ Konstanta

\section{Pengujian Pendapatan usaha (X1) Terhadap Laba Bersih (Y)}

Berdasarkan pengolahan data pada tabel 2 menunjukkan variabel pendapatan usaha (X1) memiliki nilai t hitung sebesar 8,455 . Untuk nilai $t$ tabel $(\mathrm{df})=(\mathrm{n}-\mathrm{k}-1)=85-2-1=82$, maka $(0,025$; $\beta 1=$ Koefisien regresi berganda

$\beta 2=$ Koefisien regresi berganda

$\mathrm{X} 1=$ Pendapatan Usaha

$\mathrm{X} 2$ = Biaya Operasional

$\varepsilon=$ Faktor lain diluar penelitian

\section{HASIL DAN PEMBAHASAN}

Uji t

Hasil Uji t mendeskripsikan signifikansi antara pengaruh dari setiap variabel $\mathrm{X}$ terhadap variabel Y secara parsial.

82) didapat nilai t tabel sebesar 1,98932. Maka dari itu nilai $t$ hitung lebih besar dari nilai t tabel $(8,455>1,98932)$. Nilai signifikansi $(0,000<$ $0,05)$ maka H1 diterima, artinya pendapatan usaha mempengaruhi laba bersih secara parsial.

Tabel 2 Uji Regresi Linier Berganda

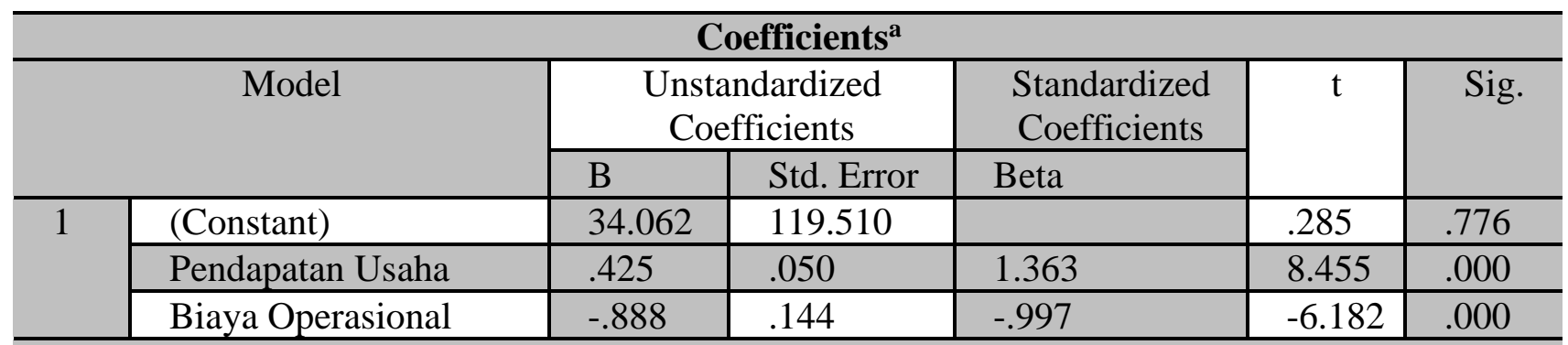

a. Dependent Variable: Laba Bersih

Berdasarkan data diatas, maka dapat disimpulkan bahwa penelitiannya menjelaskan pendapatan usaha berpengaruh secara parsial terhadap laba bersih. Hal ini terjadi karena apabila pendapatan usaha naik maka laba bersih pun akan ikut naik.

Hal ini pernah diteliti oleh (Muria, 2018) yang mengatakan bahwa secara parsial pendapatan usaha berpengaruh signifikan positif terhadap laba bersih.

\section{Pengujian Biaya Operasional (X2) Terhadap} Laba Bersih (Y)

Dari data dibawah menunjukkan variabel biaya operasional (X2) memiliki nilai t hitung sebesar -6.182. $(\mathrm{df})=(\mathrm{n}-\mathrm{k}-1)=85-2-1=82$, maka $(0,025 ; 82)$ didapat nilai $\mathrm{t}$ tabel sebesar 1,98932 . Dengan demikian nilai $t$ hitung lebih besar dari nilai t tabel $(-6.182>1,98932)$. signifikansi $(0,000$ $>0,05)$, maka H2 diterima, biaya operasional mempengaruhi secara parsial terhadap laba bersih.

Berdasarkan penjelasan tersebut, maka hasilnya mendeskripsikan bahwa laba bersih dipengaruhi oleh biaya operasional. Apabila biaya 
operasional semakin besar maka akan mengakibatkan pada menurunnya laba bersih. Apabila kegiatan perusahaan semakin meningkat maka akan berdampak pada biaya yang dihabiskan untuk operasional perusahaan juga meningkat..

Hal tersebut konsisten dengan penelitian yang dilakukan oleh (Rahmawati, 2020) yang menyatakan bahwa "laba bersih dipengaruhi oleh biaya operasional pada perusahaan manufaktur sub sektor logam dan sejenisnya".

\section{Uji F}

Uji F mendeskripsikan signifikansi antara pengaruh variabel $X$ secara simultan terhadap variabel $\mathrm{Y}$. Dari data diatas, diperoleh nilai $\mathrm{F}$ hitung sebesar 38,633. $(\mathrm{df})=(\mathrm{n}-\mathrm{k})=85-2=83$, maka $(0,05 ; 83)$ hasilnya 3,11 . Dengan demikian nilai $\mathrm{F}$ hitung lebih besar dari nilai $\mathrm{F}$ tabel $(38,633$ $>3,11$ ) dan nilai signifikansi sebesar 0,000 artinya lebih kecil dari $0,05(0,000<0,05)$.

Dengan demikian, diperoleh keputusan bahwa H3 diterima yang artinya laba bersih dipengaruhi oleh pendapatan usaha dan biaya operasional secara simultan.

Tabel 3 Uji Model

\begin{tabular}{|c|c|c|c|c|c|}
\hline \multicolumn{6}{|c|}{ ANOVA $^{\mathrm{a}}$} \\
\hline Model & $\begin{array}{l}\text { Sum of } \\
\text { Squares }\end{array}$ & df & Mean Square & $\mathrm{F}$ & Sig \\
\hline Regression & 36268249.413 & 2 & 18134124.706 & 38.633 & $.000^{\mathrm{b}}$ \\
\hline Residual & 38490716.832 & 82 & 469398.986 & & \\
\hline Total & 74758966.245 & 84 & & & \\
\hline \multicolumn{6}{|c|}{ a. Dependent Variable: Laba Bersih } \\
\hline b. Predict & (Constant), $\mathrm{Bi}$ & & ional, Pendapa & Jsaha & \\
\hline
\end{tabular}

Berdasarkan perhitungan pada tabel 4 , nilai $\mathrm{R}^{2}$ atau koefisien determinasi sebesar 0,485 atau 48,5\%. Artinya variabel dependent yaitu laba bersih dipengaruhi sebesar $48,5 \%$ oleh variabel independent yaitu pendapatan usaha dan biaya operasional. Sedangkan sebesar $51,5 \%$ variabel yang tidak diteliti oleh peneliti mempengaruhi laba bersih.

Tabel 4 R Square

\begin{tabular}{|c|c|c|c|c|}
\hline \multicolumn{5}{|c|}{ Model Summary } \\
\hline $\begin{array}{l}\text { Mo } \\
\text { del }\end{array}$ & $\mathrm{R}$ & $\begin{array}{c}\mathrm{R} \\
\text { Square }\end{array}$ & $\begin{array}{l}\text { Adjusted R } \\
\text { Square }\end{array}$ & $\begin{array}{l}\text { Std. Error } \\
\text { of the } \\
\text { Estimate }\end{array}$ \\
\hline 1 & $.697^{\mathrm{a}}$ & .485 & .473 & 685.12699 \\
\hline \multicolumn{5}{|c|}{$\begin{array}{l}\text { a. Predictors: (Constant), Biaya Operasional, } \\
\text { Pendapatan Usaha }\end{array}$} \\
\hline
\end{tabular}

Hal tersebut konsisten dengan (Efilia, 2014) yang menyatakan bahwa "laba bersih dipengaruhi oleh pendapatan usaha dan biaya operasional secara signifikan pada perusahaan jasa sub sektor transportasi yang terdaftar di BEI periode 20042013”.

\section{KESIMPULAN}

Berdasarkan pembahasan diatas bahwa dapat disimpulkan pendapatan usaha, biaya operasional dan laba bersih mengalami fluktuatif selama periode tahun 2015-2019. Berdasarkan hasil olah data dapat kita lihat pertama, laba bersih dipengaruhi oleh pendapatan usaha. Kedua, laba 
bersih dipengaruhi oleh biaya operasional . Ketiga, laba bersih dipengaruhi oleh pendapatan usaha dan biaya operasional secara simultan pada perusahaan sektor property dan real estate yang terdaftar di BEI periode 2015-2019.

\section{DAFTAR PUSTAKA}

Anjani, R. E. (2013). Pengharuh Pendapatan Usaha Dan Biaya Operasional Terhadap Laba Bersih (Survey Pada Perusahaan Jasa Sub Sektor Transportasi Yang Terdaftar Di Bursa Efek Indonesia Periode 2004-2013) THE. Universitas Komputer Indonesia, 53(9), 1689-1699.

Dirvi, D. S. A., Eksandy, A., \& Mulyadi, M. (2020). Pengaruh Growth Opportunity, Nwc, Cash Conversion Cycle, Ios Dan Leverage Terhadap Cash Holding. Jemasi: Jurnal Ekonomi Manajemen Dan Akuntansi, 16(1), 44-58.

Efilia, M. (2014). Pengaruh Pendapatan Usaha Dan Biaya Operasional Terhadap Laba Bersih Pada Perusahaan Kimia Dan Keramik, Porselin \& Kaca Yang Terdaftar Di Bursa Efek Indonesia Periode 2008-2012. 115.

Elsa, C., Munthe, C., Naibaho, J., \& Malau, Y. N. S. (2019). Analisis Pengaruh Ukuran Perusahaan Net Profit Margin Debt To Equity
Ratio Dan Perputaran Piutang Terhadap Pertumbuhan Laba Pada Pt. Sirma Pratama Nusa 2014-2017. Jurnal Mutiara Akuntansi, 4(1), 15-26.

Muria, G. (2018). Pengaruh Pendapatan Dan Biaya Operasional Terhadap Laba Bersih (Studi Kasus Pada Perusahaan Manufaktur Sektor Industri Dasar Dan Kimia Yang Terdaftar Di BEI Periode 2012-2016). Eqien: Jurnal Ekonomi Dan Bisnis, 5(1), 19-33.

Https://Doi.Org/10.34308/Eqien.V5i1.11

Pasca, Y. D. (2019). Pengaruh Pendapatan Usaha Dan Biaya Operasional Terhadap Laba Bersih Survey Pada Perusahaan Jasa Sub Sektor Transportasi Yang Terdaftar Di Bursa Efek Indonesia.

Rahmawati, L. (2020). Sub Sektor Logam Dan Sejenisnya Yang Terdaftar Di Bursa Efek Indonesia Periode 2014-2018. 5(4), 834-844.

Ratnasih, A. N. F. Dan C. (2017). Pengaruh Piutang Usaha Dan Biaya Operasional Terhadap Laba Usaha Pada PT.Nusantara Citra Terpadu Oleh: Aida Nur Fadhlia Dan Cicih Ratnasih A.

Widearahim, S. (2019). Pengaruh Biaya Operasional Dan Perputaran Piutang Terhadap Profitabilitas (Pada Perusahaan Sub Sektor Pertambangan Batubara Yang Terdaftar Di Bursa Efek Indonesia Tahun 2014-2018). Universitas Komputer Indonesia. 